\title{
Morfologinen priming ja fraseologia vieraan kielen oppimisessa: korpustutkimus oppijansuomesta
}

\author{
JARMO HARRI JANTUNEN \\ SISKO BRUNN I \\ Oulun yliopisto \\ Oulun yliopisto
}

Tiivistelmä. Artikkelimme käsittelee morfologista primingia eli taivutusmuotojen käyttöä ja muotoihin liittyviä kotekstuaalisia piirteitä. Oletuksemme on, että morfofonologisesti rikkaissa kielissä morfologinen priming on olennainen osa kielen fraseologialuonnetta, minkä vuoksi ehdotamme hypoteesia morfologisesta primingista osaksi Michael Hoeyn postulaatioita leksikaalisesta primingista (engl. lexical priming). Pilottiluonteinen tarkastelumme keskittyy lekseemeihin IHMINEN ja рітё̈̈${ }^{1}$. Tutkimusaineistona käytämme Oulun Kansainvälistä oppijansuomen korpusta (ICLFI). Analyysi perustuu korpusvetoiseen lähestymistapaan (avainsana-analyysiin), ja itse tutkimus on tehty kolmivaiheisella vertailumenetelmällä (engl. Three-Phase Comparative Analysis). Tulokset osoittavat, että morfologinen priming ja fraseologia ovat syy-seuraussuhteessa toisiinsa: kielenoppijoiden tuottama epätyypillinen fraseologisuus selittää osan natiivikielestä poikkeavasta morfologisesta primingista. Lisäksi käy ilmi, että morfologinen priming on sidoksissa myös polyseemisen sanan eri merkityksiin. Odotuksenvastaisesti lähisukukieltä puhuvat eivät kuitenkaan tuota virheettömämpiä taivutusmuotoja kuin kielenoppijat yleensä. Morfologisen primingin tarkastelu paljas-

Tarvittaessa kaikki taivutusmuodot sisältävä abstraktio eli lemma on merkitty kapiteelein, sananmuodot puolestaan kursiivein. 
tuu lopulta monisyiseksi, sillä tuotosten taustalla voivat vaikuttaa kieltenvälisen vaikutuksen lisäksi monet muutkin syyt.

Avainsanat: morfologinen priming; leksikaalinen priming; fraseologia; kieltenvälinen vaikutus; oppijansuomi; korpustutkimus

\section{Johdanto}

Suomen kielen oppimisen ja oppijansuomen tutkimus on viime vuosina haarautunut moniaalle. Yksi 2000-luvun ensi vuosikymmenen tulokas on oppijansuomen korpustutkimus; sille on viitoittanut tietä 20-vuotinen perinne oppijanenglannin korpuspohjaisessa tutkimuksessa. Englantia opiskelevien oppijoiden tuottaman kielen korpustutkimus pohjaa pitkälti firthiläis-sinclairiläiseen traditioon, jossa näkökulmana on erityisesti kielenkäyttö luonnollisissa tilanteissa. Tutkimukseen on lisäksi yhdistetty usein virheanalyysi ja oppijankielen (välikielen) vertailu natiivikieleen; Granger (1996) on käyttänyt näiden menetelmien kombinaatiosta nimeä Contrastive Interlanguage Analysis. Oppijansuomen tutkimukseen menetelmä ei ole toistaiseksi rantautunut sellaisenaan, ja tutkimuskysymyksetkin ovat muotoutuneet osittain erilaisiksi - esimerkiksi virheanalyysi ei ole noussut oppijansuomen korpustutkimuksessa samalla tavalla keskiöön.

Käsillä olevalla tutkimuksella on yhteyksiä Grangerin johtaman tutkimushankkeen keskeisiin tavoitteisiin eli oppijankielen fraseologian tutkimukseen. Useissa hankkeen tutkimuksissa (Granger 1998; Nesselhauf 2003; 2005; Meunier \& Granger 2008) on havaittu, että kielenoppijoiden tuotokset poikkeavat natiivituotoksista selvästi juuri fraseologisten piirteiden osalta. Fraseologisilla piirteillä tarkoitetaan tutkimuksissa usein kollokaatioita, vaikka fraseologisuuteen lasketaankin kuuluvaksi - Sinclairin (1991) idiomiperiaatteen mukaisesti - myös tekstikontekstin kieliopilliset ja semanttiset tasot (ks. Jantunen 2009b). Koska tutkimus on keskittynyt nimenomaan englannin ja joidenkin muiden indoeurooppalaisten kielen tutkimukseen, eivät morfologiset piirteet ole juurikaan saaneet huomiota (natiivi- ja) oppijankielen 
korpustutkimuksessa. Taivutukseltaan monipuolisen kielen oppimista koskevassa tutkimuksessa morfofonologisten piirteiden tarkastelu osana kielen fraseologisuutta on kuitenkin olennaista: fraseologisen yksikön ydin ja kotekstuaaliset elementit suosivat yleensä tiettyjä taivutusmuotoja. Tässä artikkelissa pyritään kuvaamaan fraseologisten yksiköiden ja morfologisen vaihtelun yhteenkuuluvuutta kahden tapaustutkimuksen avulla: korpusanalyysin perusteella tutkittaviksi tapauksiksi valikoituivat nomini IHMINEN ja verbi PITÄ̈̈. Niiden avulla on tarkoitus testata hypoteesia ns. morfologisen primingin merkityksestä fraseologisuudessa ja kielenoppimisessa, joskaan mitään yleistä kuvausta morfologian ja fraseologian keskinäisestä suhteesta oppijankielessä (tai natiivikielessä) ei tapaustutkimusten perusteella voikaan antaa.

\section{Leksikaalinen priming ja fraseologia}

Psykolingvistiikan - ja laajemminkin psykologian, muistin ja oppimisen tutkimuksen - käsite priming tarkoittaa ärsykkeeseen tai ennakkotietoon perustuvaa ennakointia, virittäytymistä ja reagointia. Kun henkilö havaitsee jonkin ärsykkeen, esimerkiksi kuvan tai sanan, havaittu ärsyke aktivoi siihen liittyviä aiemmin koettuja tapahtumia, kokemuksia, käsitteitä, sanoja tai ilmauksia. Näin ollen aiemmin havaittu ja opittu vaikuttaa myöhempään oppimiseen ja esimerkiksi kielellisiin tuotoksiin. Aiemmat kokemukset säilyvät implisiittisessä muistissa, josta ärsyke ne aktivoi ja joka helpottaa muun muassa uuden oppimista ja mieleen palauttamista. Mitä useammin samanlainen ärsyke on aktivoinut tietyntyyppisen reaktion, sitä helpommin odotuksenmukainen priming toteutuu; niinpä esimerkiksi länsimaisen ihmisen ei syödessään tarvitse erikseen miettiä, miten haarukkaa käytetään, vaan tieto on hänen implisiittisessä muistissaan ja aivot ovat valmistautuneet tuottamaan tietyn prosessoinnin. Vastaavasti syömäpuikkoihin tottunut ei joudu erityisesti pohtimaan niiden käyttämistä.

Ärsykkeen tuottamasta aktivoitumisesta käytetään käsitettä priming-efekti. Psykolingvistisessä tutkimuksessa on tarkasteltu semant- 
tista virittäytymistä erityisesti sanaparitesteillä (ks. mm. Neely 1991; McNamara 2005): kun sanaparin sanat kuuluvat samaan merkityskenttään, ensimmäinen sana aktivoi onnistuneesti ja nopeasti seuraavan sanan, mutta aivan eri merkityskenttään kuuluva sana puolestaan häiritsee ja hidastuttaa jälkimmäisen sanan tuottamista tai tunnistamista. Niinpä esimerkiksi sanojen tunnistamistestissä (epäsanat vs. todelliset sanat) todellisista sanoista tunnistetaan nopeammin ne, joita edeltävä ärsyke on samaan merkitysryhmään kuuluva (engl. nurse-doctor), kuin ne, joita edeltää toiseen ryhmään kuuluva sana (engl. bread-door) (McNamara 2005: 3). Tunnistamisen helppous riippuu merkitysten läheisyydestä ja siitä, kuinka taajaan sanat esiintyvät yhdessä.

Michael Hoey on puolestaan tehnyt tunnetuksi käsitteen leksikaalinen priming (engl. lexical priming). Tämä käsite on kuitenkin pidettävä erillään psykolingvistiikan priming-käsitteestä, joka liittyy edellä kuvatulla tavalla ärsykkeen aikaansaamaan reaktioon koetilanteessa. Näin ollen tutkimaamme ilmiötä ei voi pitää psykolingvistiseen priming-tutkimukseen kytkeytyvänä, vaan se kuvaa kielen fraseologista luonnetta. Siinäkin on kyse eräänlaisesta virittäytymisestä sanojen tyypilliseen käyttöön, mutta priming on kuitenkin määritelty hieman toisin tarkoittamaan kielenomaksumisen aikana kielitietoon muodostunutta skeemaa sanojen tyypillisestä käytöstä:

--- when we use the word, we will characteristically use it with one of its typical collocations, in its usual grammatical function, in the same semantic context, in the domain we have come to associate it with, as part of the same genre, in a familiar social context, with a similar pragmatics and to similar textual ends. (Hoey 2007: 8.)

Hoeyn näkemys sanojen tyypillisten käyttöyhteyksien hallinnasta on siis varsin holistinen, ja se kattaa Sinclairin (1996) määritelmän merkitysyksiköstä ytimineen ja sen kontekstuaalisine valintasuhteineen. Priming liittyy siis laajasti fraseologiaan: ilmauksilla on odotuksenmukaiset käyttöyhteytensä alkaen tyypillisistä kerasanoista eli kollokaateista aina tyylillisiin ja tekstuaalisiin preferensseihin asti. Käyttöyhteyksien omak- 
sumisessa kertautumisella on erittäin suuri merkitys. Samalla tavalla kuin sanojenkin omaksuminen perustuu toistumiseen, myös kontekstuaalisten suhteiden hallintaan tarvitaan prosessi, jossa tietyt rakenteet toistuvat taajaan. Niinpä natiivi kielenkäyttäjä "tietää”, että voi härskiintyy tai eltaantuu, leipä ja hillo homehtuvat, mutta maito puolestaan happanee. Härskiintyä voivat voin lisäksi myös öljyt, margariinit, rasvat ja esimerkiksi runsaasti rasvaa sisältävät kalat, kuten lohet. Niinpä rasvahappojen hapettumista tarkoittavalla härskiintymisellä on semanttinen preferenssi (ks. esim. Jantunen 2009b) rasvoja tai niitä runsaasti sisältäviä ruoka-aineita merkitseviin sanoihin. Tämä näkyy siinä, että kielenkäyttäjät käyttävät verbiä tyypillisesti tällaisten sanojen kanssa. Natiivin kielenkäytössä priming näyttäytyy siis juuri toistuvina käyttöyhteyksinä. Sanojen fraseologisuuteen kuuluukin runsaasti erilaista konkreettista ja abstraktia tietoa sen käytöstä; tässä yhteydessä fraseologisuudella tarkoitetaan siis huomattavasti laajempaa sanastollis-kieliopillis-semanttista ja tekstuaalista ilmiötä kuin yleensä puhuttaessa esimerkiksi idiomeista, metaforisista ilmauksista tai sanonnoista.

\section{Kielenoppiminen ja leksikaalinen priming}

Kun S2-kielenkäyttäjä tuottaa lauseen Ulkona ei ole erittäin kaunis ilma, on hän muodostanut kieliopillisesti kelvon rakenteen - ja huomattakoon, että myös ymmärtämisen näkökulmasta onnistuneen ilmauksen. Fraseologisuuden näkökulmasta se on kuitenkin epätyypillinen: erittäin ei kollokoi kieltoverbin kanssa, eikä sillä ole negatiivista semanttista prosodiaa. Tällä hetkellä tutkimuskirjallisuudessa (ks. esim. Wray 1999; 2000; Nesselhauf 2005; Tsui 2004; 2005; Ellis 2008; Meunier \& Granger 2008) ollaan yksimielisiä siitä, että kohdekielen fraseologisuus on yksi vaikeimmin omaksuttavista ja opetettavista asioista, mutta natiivin kaltaisen kielenkäytön tavoittamisen kannalta sen hallinta on kuitenkin tärkeää. Fraseologisuuden ymmärtäminen ja kyky muodostaa kohdekielen mukaisia ilmauksia ovat nimittäin yhteydessä puhutun ja kirjoitetun kielen sujuvaan käyttöön. Lisäksi syötöksen ymmärtäminen nopeutuu 
ja helpottuu, kun viestin vastaanottaja pystyy hahmottamaan syötöksestä tuttuja, valmiita kokonaisuuksia sen sijaan, että jokaisen yksittäisen ilmauksen merkitys ja suhde toisiin ilmauksiin pitäisi analysoida itsenäisinä ja erikseen. Reseptiivisen ja produktiivisen sujuvuuden kehittymisen lisäksi fraseologinen tieto auttaa myös rekisterien ja tekstityyppien hallinnassa, sillä niiden konventioihin kuuluu oleellisena osana omanlaisensa fraseologisuus.

Leksikaalinen priming säilyy kielenoppijan ongelmana pitkään, sillä vielä hyvin edistyneetkin kielenoppijat tuottavat kohdekielen fraseologisesta normistosta poikkeavia muotoja (Granger 1998; Hasselgren, 1994; Nesselhauf 2005; 2009). Luultavaa on, että taajaan esiintyvät ja morfosyntaktisesti selvästi vakiintuneet fraseologiset rakenteet, kuten keskustelurutiinit, omaksutaan helpommin kuin (ainakin teoreettisesti) vapaat yhdistelmät. Tähän asti fraseologisuuden problematiikassa on ollut tutkimuksen kohteena nimenomaan kollokaatioiden hallinta ja muiden piirteiden analyysi on jäänyt mitättömäksi. Kielenoppijoiden tuotoksista on esimerkiksi havaittu, että oppijat keskittyvät käyttämään tiettyjä frekventtejä kollokaatioita, jolloin reseptiivinen ja produktiivinen käyttö helpottuvat näiltä osin, mutta kohdekielessä ilmenevä kollokaatiokirjo jää oppijoilta tavoittamatta. Toisaalta oppijat tuottavat runsaasti myös kohdekielestä poikkeavia kollokaatioita. Tähän ovat syynä yhtä hyvin kollokaationormiston hallinnan puute kuin myös kielenoppijan luontainen tarve pyrkiä luovaan ja kokeilevaan kielenkäyttöön. (Granger 1998; Kaszubski 2000; Nesselhauf 2005.) L2-oppijoiden kollokaatioita on tarkasteltu korpusaineistojen avulla jo myös suomen kielen oppijoiden tuotoksista (ks. Kallioranta 2009), mutta tutkimustieto koostuu edelleen lähinnä englannin oppimisesta tehdyistä havainnoista. Yhtä kaikki fraseologisuuden tutkimus on raapaissut toistaiseksi vain pintaa, sillä monet sen ilmiöt - kuten tässä artikkelissa analysoitava morfologinen priming - ovat jääneet vielä huomiotta. Lisäksi huolimatta siitä, että kollokaatioiden oppimista on analysoitu runsaasti, ei niiden (saati muiden fraseologisten piirteiden) opettamisen metodisessa kehittämisessä ole päästy vielä kovinkaan pitkälle - ei edes englantia opetettaessa. 
Kollokaatioiden oppimisen tutkimuksessa on keskitytty pitkälti kielenoppijoiden tuotoksen ja natiivituotoksen vertailuun sen sijaan, että opetuksen tueksi olisi selvitetty natiivien tuotoksissa ilmeneviä säännönmukaisuuksia. (Nesselhauf 2005: 3, 6.)

\section{Morfologinen priming}

Kun tarkastellaan morfofonologisesti rikkaiden kielten, kuten suomen, fraseologiaa, kohtaa analyysi haasteita: pitäydytäänkö fraseologisen yksikön analyysissa lemmatasolla eli abstraktissa perusmuodossa (kuten IHMINEN vs. ihminen, ihmisen, ihmistä...) vai otetaanko tarkasteluun mukaan myös taivutusmuodot ja niissä ilmenevä variaatio (esim. ihmisten vs. ihmisien). Aiempi, erityisesti englantia koskeva fraseologiatutkimus ei ole juuri kiinnittänyt luonnollisista syistä taivutukseen kovinkaan paljon huomiota. Suomen kielessä taipuminen on kuitenkin merkittävä ominaisuus sekä fraseologisen yksikön ytimen (engl. core) että sen kotekstuaalisten kerailmausten näkökulmasta: molemmathan taipuvat morfosyntaktisten vaatimusten ja rajoitusten mukaisesti, eli niillä on tietty odotuksenmukainen priming johonkin taivutusmuotoon. Niinpä natiivin suomen kielen puhujan priming ei toteudu pelkästään tiettyinä kotekstuaalisina leksikaalisina ja semanttisina valintoina vaan myös itse ytimen ja sen kerailmausten taivutusmuotoina. Tätä ilmiötä kutsumme seuraavassa esityksessä fraseologisen yksikön morfologiseksi primingiksi. Aiemmin ilmiöstä on käytetty myös nimitystä morfologinen preferenssi (Jantunen 2004a), joka jakautuu paradigmaattiseen ja kontekstuaaliseen taivutusmuotojen preferenssiin. Käsillä olevassa artikkelissa käytämme kuitenkin käsitettä morfologien priming, koska haluamme liittää ilmiön laajempaan leksikaalisen primingin käsitteeseen. Ilmiöön on viitannut aiemmin myös Hoey (2005: 159) primingin ja kieliopin suhdetta käsitellessään, mutta teoria leksikaalisesta primingista ei kuitenkaan ota fraseologisen yksikön morfologisia piirteitä huomioon. Oletuksemme kuitenkin on, että morfologisen primingin käsitteleminen on oleellista fraseologisia yksiköitä 
tutkittaessa; niinpä esitämmekin Hoeyn (2005: 13) hypoteeseja mukaillen seuraavaa:

Jokaisella sanalla on oma morfologinen priminginsa, eli se esiintyy tyypillisesti ja frekventisti yhdessä tai useammassa morfofonologisessa muodossa, ja myös sen kotekstissa esiintyvistä ilmauksista on löydettävissä omat odotuksenmukaiset taivutusmuotonsa.

Oletus tiettyjen taivutusmuotojen tyypillistymisestä ei ole tietystikään uusi: on yhtäältä esitetty, että sanalla voi olla käytössä vain tiettyjä taajaan käytettyjä taivutusmuotoja, ja toisaalta, että tietyillä taivutusmuodoilla voi olla oma kontekstuaalinen preferenssinsä. Ensimmäisestä tapauksesta käy esimerkiksi synonyymipari TÄRKEÄ ja KESKEINEN, joista TÄRKEÄ esiintyy eniten partitiivimuotoisena ja melko taajaan komparoituna mutta sen synonyymi puolestaan nominatiivissa ja yleensä positiivimuotoisena (Jantunen 2001). Jälkimmäisestä antaa esimerkin Tognini-Bonelli (1996: 74, 77-80): italian tietää-verbin vastineen vaihtoehtoiseksi väitetyillä saper- ja sapere-infinitiivimuodoilla on osoittautunut olevan omat syntagmaattiset valintansa. Näistä ensimmäistä käytetään nimittäin yleensä infinitiivimuotojen, jälkimmäistä sivulauseiden yhteydessä. Suomen kielen kauniiksi ja kauniilta saavat puolestaan selvästi erilaiset kollokaatit ja semanttiset preferenssit: kauniiksi $<$ mm. SANOA, KEHUA, TEHDÄ, MUUTTUA > (eli puhumista ja muuttumista ilmaisevat kollokaatit) ja kauniilta <NÄYTTÄ̈̈, VAIKUTTAA, KUULOSTAA (eli näyttää tai kuulostaa joltakin) (Jantunen 2004a: 27-28). Vastaavanlaisia oletuksia eri taivutusmuotojen kontekstuaalisesta sidoksisuudesta on muitakin (ks. Sinclair 1991: 8; Aston \& Burnard 1998: 8). Sinclair (1991: 8) ja Stubbs (2001:17) jakavatkin käsityksen, että leksikaalisia (fraseologisia) yksiköitä pitäisi tarkastella lemmatasolla ainoastaan, mikäli lemman taivutusmuotojen syntagmaattiset valinnat olisivat yhteneviä. Tämä toteutunee kuitenkin harvoin.

Sen lisäksi että kielenoppijalla on runsaasti mahdollisuuksia päätyä epätyypillisiin leksikaalis-semanttisiin rakenteisiin tuottaessaan kohdekielen fraseologisia yksiköitä (ks. Jantunen 2009b), ongelmia tuottavat myös morfologiset piirteet nimenomaan fraseologian näkökulmasta. 
Monet yksittäiset morfofonologian ja morfosyntaksin piirteet liittyvätkin fraseologisten sääntöjen tunnistamisen, osaamisen ja opettamisen vaikeuteen: oppijalla ei ole yleensä tietoa ilmausten frekventeimmistä ja siten myös osaamisen kannalta tärkeimmistä muodoista eikä myöskään niiden kotekstuaalisista (kuten kolligationaalisista) ja tekstinulkoisen maailman (tilannekontekstin) suhteista. Esimerkiksi valenssisääntöjen hallinta pohjautuu fraseologiasääntöjen havaitsemiseen ja ymmärtämiseen ja sisältää niin leksikaalisten, kieliopillisten ja semanttisten samoin kuin tekstin ulkoisten säännöstöjen osaamisen. Tämä monimutkainen sääntöverkosto on natiivin kielenkäyttäjän pääasiassa implisiittisesti hallitsema, eikä sen auki purkaminen ole yksiselitteistä kokeneellekaan opettajalle.

\section{Aineisto ja menetelmät}

Tapaustutkimusten aineistona käytämme Oulun Kansainvälistä oppijansuomen korpusta (ICLFI, ks. Jantunen 2011b). Aineisto koostuu ulkomaisissa yliopistoissa opiskelevien suomenoppijoiden kirjoitetuista teksteistä. Korpuksen tekstit ovat opetustilanteessa tuotettuja harjoitustöitä tai kokeita. Aineistossa on sekä fiktiivisiä ( $\mathrm{mm}$. kertomuksia ja kirjeitä) että asiatekstejä (mm. arvosteluja ja esseitä), ja niiden kokonaismassa muodostaa maaliskuussa 2012 n. 5300 tekstin ja n. miljoonan saneen tekstikokonaisuuden.

Tätä tutkimusta varten on aineistosta muodostettu kaksi osakorpusta: ICLFI-viro on osakorpus, joka sisältää noin 104000 saneen (579 tekstiä) verran vironkielisten oppijoiden kirjoituksia. ICLFI-multi on puolestaan niin sanottu moniäidinkielinen korpus, jossa on tekstejä eri kieliä äidinkielenään puhuvilta opiskelijoilta. Suurimmat aineistot muodostuvat puolaa, venäjää, saksaa, ruotsia, tšekkiä, kiinaa ja hollantia äidinkielenään puhuvien suomenoppijoiden teksteistä. Yhteensä eri äidinkielitaustoja on ICLFI-multissa 21, jokin eräiden osakorpusten tekstit (kuten ranskan-, japanin- ja marinkielisten tekstit) muodostavat hyvin pienen tekstijoukon. ICLFI-multi-aineiston koko on noin 698000 
sanetta ja 3144 tekstiä. Vertailuaineistona käytetään Käännössuomen korpuksesta (Mauranen 2000) luotua natiivisuomen aineistoa, joka on noin 4 miljoonan saneen fiktiivisiä ja asiatekstejä sisältävä korpus.

Kahden oppijansuomen tutkimusaineiston käyttöä motivoi kolmivaiheinen vertailumenetelmä (engl. Three-Phase Comparative Analysis, TPCA), jota on aiemmin testattu käännöskielen tutkimuksessa (Jantunen 2004b; ks. myös Kubáčková 2009; Dose 2010). Menetelmässä yksi osakorpus muodostuu kielitaustaltaan vain yhden yhtenäisen ryhmän teksteistä (tässä vironkielisten tekstit), kun taas toinen osakorpus koostuu kielitaustaltaan varioivista teksteistä eli se edustaa tutkittavaa varianttia yleensä, tässä tutkimuksessa siis laajasti oppijansuomea. Kolmivaiheinen vertailu syntyy tarkasteltaessa oppijankieliaineistoja suhteessa toisiinsa ja molempia erikseen suhteessa natiiviaineistoon. Vertailun tavoitteena on saada selville, poikkeavatko aineistot toisistaan joidenkin kielenpiirteiden osalta. Jos eroja esiintyy korpusten välillä, voidaan olettaa, että erot johtuvat kielitaustasta. Kuitenkin kuten todellisia tekstejä käyttävissä tutkimuksissa yleensä, on myös nyt pidettävä mielessä se, että monien muiden taustamuuttujien (kuten muiden kielten osaamisen ja vaikkapa oppimateriaalin merkityksen) poissulkeminen on mahdotonta.

Tässä artikkelissa tutkittavien kielenainesten valinta on tehty korpusvetoisesti. Korpusvetoisuus tarkoittaa yksinkertaistetusti sitä, että tutkittavia aineksia ei valita aiempiin tutkimuksiin perustuen tai tutkijan intuition perusteella, vaan ne nousevat aineistosta esiintymistiheytensä perusteella. Yksi tavallisimmasta korpusvetoisista menetelmistä on avainsana-analyysi. Siinä aineistoja verrataan tilastollisin menetelmin keskenään, ja vertailun tulokseksi saadaan avainsanoja eli sanoja (tai sananmuotoja), jotka esiintyvät tutkimusaineistossa huomattavasti tiheämmin kuin vertailuaineistona käytettävässä materiaalissa. (Korpusvetoisuudesta ja avainsana-analyysista tarkemmin esim. Scott \& Tribble 2006; Jantunen 2009a; Jantunen 2012.) Tutkimuksessamme olemme käyttäneet lähtökohtana koko ICLFI:n vertailua natiiviaineistoon saadaksemme selville, millaiset tutkimusaineiston sanat poikkea- 
vat frekvenssiltään natiiviaineistosta. WordSmith Toolsin (Scott 2004) Keywords-työkalun avulla saatu avainsanalista, eli oppijoiden suosimien sanojen lista, sisältää ensinnäkin runsaasti sellaisia sanoja, joiden runsaan lukumäärän voi selittää opiskelijoiden kirjoittamien tekstien tehtävänannoilla: sanat kuten KIINA, SINUHE, TIMO, YLIOPISTO ja OPISKELLA selittyvät helposti kirjoitustehtävillä eivätkä siis ole mielenkiintoisia, kun tavoitteena on kuvata nimenomaan kielenoppisen ja oppijankielen piirteitä. Tutkimukseemme olemme valinneet avainsanalistalta sanat IHMINEN ja PITÄÄ, jotka esiintyvät eri muodoissaan tilastollisesti merkitsevimpien oppijankielen avainsanojen listalla, kun oppijanaineistoa verrataan natiiviaineistoon; IHMINEN-nominin tilastollisesti yliedustunein muoto on ihmiset ja PITÄ̈̈-verbin pitää ja pidän.

Seuraavaksi tarkastelemme, miksi tietyt muodot ja koko lemma ylipäätäänkin esiintyvät oppijankieliaineistossa niin taajan. Tavoitteenamme on etsiä morfologian ja fraseologian yhtymäkohtia ja tarkastella fraseologisten piirteiden selitysvoimaa morfologisten piirteiden epätyypillisten esiintymämäärien kuvauksessa. On toki luonnollista, että kahden sanan tarkastelulla ei voida laajasti selittää oppijansuomen morfologista primingia ja fraseologisten piirteiden syy-yhteyttä morfologisessa primingissa onnistumiseen. Tuloksia on siten pidettävä alustavina ja tutkimusta pilottiluonteisena: tarkoituksena on selvittää morfologisen primingin olemusta, hypoteeseja ja lisäksi myös aineiston merkitystä tutkimuksessa.

\section{Tapaustutkimukset IHMINEN ja PITÄÄ}

\subsection{Tapaus IHMINEN}

IHMINEN-nominin analyysissa keskitymme kieliopillisten sijojen analyysiin, sillä ne ovat odotetusti taajimmin esiintyviä muotoja aineistoissa ja näin ollen analyysin näkökulmasta myös frekvenssiltään riittäviä (kieliopillisten sijojen osuus kaikista sijoista on jokaisessa aineistoissa yli 80 \%). Kun kieliopillisissa sijoissa taivutettujen muotojen ja muiden muotojen yhteenlaskettua määrää tarkastellaan tilastollisesti, paljas- 
tuu alustavasti, että muotojen määrät poikkeavat aineistoittain erittäin merkitsevästi toisistaan $\left(\mathrm{x}^{2}=256,8(\mathrm{df}=6, \mathrm{p}<0,0001\right.$, kriittinen arvo $22,46)$ ). Näyttää siis siltä, että oppijan- ja natiivikielen aineistot erottuvat toisistaan siinä, missä kieliopillisissa sijoissa IHMINEN esiintyy näissä kielivarianteissa. Yksityiskohtaisempi tarkastelu paljastaa, että molemmissa oppijanaineistoissa kieliopillisissa sijoissa taivutettujen muotojen määrä poikkeaa natiiviaineistosta ja että ICLFI-multi-aineisto poikkeaa natiivituotoksista enemmän kuin vironkielisten oppijoiden kirjoittamat tekstit. Sekä yksikkö- että monikkomuotojen yli- ja alikäyttö on kirjattu muodoittain ja aineistoittain taulukkoon 1 tilastollisesti merkitsevimmin erottuvien muotojen osalta. Moniäidinkielisessä aineistossa partitiivin yksikkömuotoa lukuun ottamatta kaikkien kieliopillisissa sijoissa esiintyvien muotojen taajuudet poikkeavat natiivikielen aineistosta. Sen sijaan virolaisten suomenoppijoiden tuotokset noudattavat sijojen osalta natiivin kaltaista kielenkäyttöä, poikkeuksena jälleen partitiivin yksikkömuodot, joita vironkieliset oppijat käyttävät runsaammin kuin natiiviaineisto antaisi olettaa.

Seuraavaksi keskitymme muotojen ylikäyttötapauksiin ${ }^{2}$. Muotojen tavanomaista suuremmille frekvensseille tarjoutuu useita selityksiä, joiden juuret palautuvat kielen fraseologialuonteeseen. Ensinnäkin NOM. PL-muodon ylikäyttö ICLFI-multi-aineistossa selittyy osittain impersonaalisen passiivin (esim. mennään) välttämisellä ja sen korvaamisella ihmiset-rakenteella $(1,2)$. Geneerinen IHMINEN passiivin korvaajana (mm. nollapersoonan ohella) onkin Seilosen (2011) mukaan yksi suomenoppijoiden strategisista keinoista; impersonaalisen passiivin onnistunut käyttö puolestaan lisääntyy kielitaidon kehittyessä (Martin ym. $2010)^{3}$.

\footnotetext{
2 Myös alikäyttötapaukset ovat oppijankieliaineiston kuvauksen kannalta relevantteja, mutta käsillä olevassa tutkimuksessa ei ole mahdollista perehtyä niihin, koska sellaisten elementtien analyysi, joita aineistossa ei ole, vaatii erityisen tarkan perehtymisen natiivikieliseen tuotokseen ja tulosten vertailun muihin aineistoihin. Tässä tutkimuksessa on kuitenkin otettu lähtökohdaksi oppijankieliaineistot.

3 Passiivin lisääntyminen näkyy myös ICLFI-aineistossa, sillä passiivimuotojen määrät moninkertaistuvat siirryttäessä alkeista keskitasolle ja edistyneelle tasolle.
} 
Taulukко 1. Kieliopillisten sijojen yli- ja alikäyttö oppijankielen aineistoissa natiiviaineistoon verrattuna $\left(^{* * *}=\text { erittäin merkitsevä, } \mathrm{z}>3,29(=\mathrm{p}<0,001)\right)^{4}$

\begin{tabular}{|l|l|l|l|}
\hline \multicolumn{2}{|c|}{ ihminen-nomini } & \multicolumn{1}{c|}{ ICLFI-viro } & \multicolumn{1}{c|}{ ICLFI-multi } \\
\hline NOM.SG & ihminen & - & alikäyttö \\
\hline NOM.PL & ihmiset & - & ylikäyttö \\
\hline GEN.SG & ihmisen & - & alikäyttö*** \\
\hline GEN.PL & ihmisten/ihmisien & - & alikäyttö̈** \\
\hline PTV.SG & ihmistä & ylikäyttöö & - \\
\hline PTV.PL & ihmisiä & - & ylikäyttö $^{* * *}$ \\
\hline
\end{tabular}

(1) Kirkon jälkeen ihmiset menevät kotiin syömään. (SA0106A)

(2) --- on kuvaavaa, että ihmiset puhuvat murteita vain pienemmissä kylissä eikä kaupungeissa. (UN0014A)

Tämän lisäksi oppijat käyttävät toistuvasti kyseistä NOM.PL-muotoa eksplisiittisissä ja redundanteissa rakenteissa, joissa sitä edeltää kvanttoripronomini (3 ja 4). Kvanttoripronominit, kuten KAIKKI, MONI, JOKAINEN ja JOKU, viittaavat yksinäänkin esiintyessään joukkoon ihmisiä (Monelle on varmaan tuttu tilanne se, että --- , ISK $2004 \$ 744$ ), joten

$4 \quad$ NOM.sG: ICFLI-viro vs. natiiviaineisto $\mathrm{z}=0,348$ ( $\mathrm{p}>0,05)$, ICLFI-multi vs. natiiviaineisto $\mathrm{z}=8,059(\mathrm{p}<0,001)$

NOM.PL: ICFLI-viro vs. natiiviaineisto $\mathrm{z}=0,722(\mathrm{p}>0,05)$, ICLFI-multi vs. natiiviaineisto $\mathrm{z}=15,417(\mathrm{p}<0,001)$

GEN.SG: ICFLI-viro vs. natiiviaineisto $\mathrm{z}=0,873(\mathrm{p}>0,05)$, ICLFI-multi vs. natiiviaineisto $\mathrm{z}=15,884(\mathrm{p}<0,001)$.

GEN.PL: ICFLI-viro vs. natiiviaineisto $z=1,617$ ( $p>0,05)$, ICLFI-multi vs. natiiviaineisto $\mathrm{z}=4,391(\mathrm{p}<0,001)$.

PTV.SG: ICFLI-viro vs. natiiviaineisto $\mathrm{z}=10,941$ ( $\mathrm{p}<0,001)$, ICLFI-multi vs. natiiviaineisto $\mathrm{z}=0,492(\mathrm{p}>0,05)$.

PTV.PL: ICFLI-viro vs. natiiviaineisto $z=0,589$ ( $p>0,05)$, ICLFI-multi vs. natiiviaineisto $\mathrm{z}=7,611(\mathrm{p}<0,001)$.

$5 \quad$ Koodissa kirjainyhdistelmä yksilöi äidinkielen (ES = espanja, IS = islanti, $\mathrm{KI}=$ kiina, $\mathrm{PU}=$ puola, $\mathrm{SA}=$ saksa, $\mathrm{UN}=$ unkari, $\mathrm{VE}=$ venäjä, $\mathrm{VI}=$ viro), numerosarja kirjoittajan ja viimeinen merkki tekstin. 
NOM.PL-muodon käyttö ei sinänsä tuo ilmaukseen lisäinformaatiota vaan on merkityksen näkökulmasta redundantti. Fraseologisesta näkökulmasta tarkasteltuna ihmiset näyttääkin kolligoivan ICLFI-multiaineistossa epätyypillisen taajaan kvanttoripronominien kanssa: kun natiiviaineistossa kaikki ihmiset ja monet ihmiset esiintyvät miljoonaa sanetta kohti kuusi ja seitsemän kertaa, ovat multi-aineiston vastaavat suhdeluvut 54 ja 131 .

(3) Yhtäkkiä kaikki ihmiset huutaivat ja matkatavaroita sijaitsivat lattialla. (SA0023B)

(4) Mutta monet ihmiset sanovat Pekingin ilmanlaatu ei ole hyvä ---. (KI0016Q)

Toinen samassa aineistossa yliedustunut muoto on PTV.PL ihmisiä. Taajan käytön osittaiseksi selitykseksi paljastuvat eksistentiaalilauseet, joissa kvantifioidaan ihmisten määrää jossakin tietyssä paikassa (5). Muoto on odotuksenmukainen kvanttoriadverbien jälkeen, sillä niitä seuraa NP.PTV (ISK $2004 \$ 657$ ). Yliedustumisen syynä ei siten ole muodon käyttö sinänsä vaan pikemminkin se, että oppijoilla on kirjoituksissaan (kuten esimerkiksi kuvauksissa) taipumus korostaa vastaanottajan kannalta tai omasta mielestään tärkeitä, uniikkeja tai outoja ilmiöitä (Jantunen 2007; Kallioranta 2009). Oppijat korostavat teksteissään ihmispaljouden lisäksi usein myös oletettuun tai todelliseen kokemuspiiriin kuulumattomia ilmiöitä käyttämällä eksistentiaalilauseissa juuri kvantifiointia (6). Paljon-kvantifiointi onkin erittäin yleistä suomenoppijoiden teksteissä, ja paljon on myös yksi niin sanotuista oppijansuomen avainsanoista (Jantunen 2011a).

(5) Minun täytyy sanoa, että Puolassa on paljon viisaita ihmisiä. (PU0008D)

(6) Lapissa on paljon lunta. (KI0010M)

Muodon runsaudelle on lisäksi löydettävissä selitys kvanttoriadverbin ja kvanttoripronominin sekoittumisesta: jopa 29 \% paljon ihmisiä-tapauksista olisi korvattava kvanttoripronominin sisältävällä rakenteella (esim. 
monet ihmiset tai useat ihmiset), jolloin myös nominin pitäisi olla odotuksenmukaisesti toisessa sijassa (NOM.PL), kuten esimerkissä (7), johon sopisi paremmin monet/useat ihmiset.

(7) Selitetäänkin, että paljon ihmisiä jatkavat opiskella aikuisina, jopa työn ohessa. (IS0002I)

Tässä yhteydessä on kuitenkin huomattava, että oppijat ovat hallinneet NP:tä koskevan sijamuotovalinnan (paljon + NP.PTV), mutta tuottavat odotuksenvastaisen muodon nimenomaan kvanttorin valinnan näkökulmasta. Kun PTV.PL-ylikäyttötapauksia tarkastelee jälleen fraseologisuuden näkökulmasta, voi havaita selvästi, että ICLFI-multi-aineistossa PTV.PL kolligoi siis voimakkaasti kvanttoreiden ja eksistentiaalilauseiden kanssa, ja erityisesti kollokointi kvanttoriadverbin paljon kanssa on tyypillistä.

Kolmas ylikäyttötapaus löytyy edellisistä poiketen vironkielisten oppijoiden tuotoksista: ihmistä (PTV.SG) esiintyy tässä osakorpuksessa merkitsevästi useammin kuin yleensä kohdekielisessä tuotoksessa. Yhdeksi selitykseksi nousevat aineistosta jälleen eksistentiaalirakenteet, tällä kertaa esittelevät, perhettä kuvaavat rakenteet: perheessä(ni) on \# ihmistä (8 ja 9). Rakenteita on lukumääräisesti vähän $(\mathrm{n}=9)$, mutta ne kattavat PTV.sG-tapauksista kuitenkin kolmasosan. (Rakenne näyttää olevan tätäkin taajemmin esiintyvä, sillä rakenteen määrä nousee 63:een, kun aineistoa laajennetaan tutkimusaineiston kokoamisen jälkeen saaduilla teksteillä; PTV.SG-muodossa oleva ilmaus voi olla myös (perheen)jäsentä.) Näissä rakenteissa PTV.SG määrittää rakenteen edussanana olevaa nominatiivimuotoista numeraalia ja on tässä rakenteessa siis odotuksenmukainen. Näille rakenteille löytyy selitys opetuksessa annetuista tehtävänannoista, sillä ovathan minun perheeni -tyyppiset tekstit erittäin tavallisia juuri alkeistason opetuksessa, kun harjoitellaan sukulaisuusnimityksiä ja esimerkiksi lukusanoja, omistus- ja eksistentiaalirakenteita. Näin ollen ylikäytön syyksi paljastuu ainakin osittain itse tehtävänanto eikä kysymyksessä ole tältä osin niinkään kieleen liittyvä ilmiö. 
(8) Minun perheessä on yhdeksän ihmistä. Perheeseeni kuuluu äiti, isä, 3 siskoa... (VI0284)

(9) Minun perheessäni on viisi ihmistä ja minä on olen nuorin perhejäsen. (VI0064E)

Ymmärrettävyyden ja kieliopillisuuden näkökulmasta tässä perheessäni on \# ihmistä -rakenteessa ei ole mitään ongelmaa: kirjoittajat noudattavat suomen kielen tyypillistä eksistentiaalirakenteen kaavaa, ja ilmaus on läpinäkyvä ja ymmärrettävä. Yllättäen natiiviaineistoja analysoimalla kuitenkin paljastuu, että rakenne ei ole tavallinen suomalaisissa kirjoitetuissa teksteissä. Tutkimuksessa käytetyssä natiiviaineistossa rakennetta ei esiinny olenkaan, mikä voi tosin johtua tekstien aihepiireistä. Lisävarmistusta varten tehty Google-hakukoneella suoritettu haku ${ }^{6}$ vahvistaa rakenteen kuitenkin erittäin harvinaiseksi: sitä löytyy internetistä hakukoneen avulla vain kolmetoista tapausta. Näin ollen rakenne paljastuu käytön kannalta epätyypilliseksi; selvästi tavallisempi tapa kertoa perheenjäsenistä on luetteloida henkilöt hyponyymeinä ilman merkitykseltään yleistä ihmistä-sanaa, esimerkiksi Perheessäni on isä, äiti ja 2 siskoa. Tekstien taustatietojen analyysi paljastaa mielenkiintoisesti, että perheessäni on \# ihmistä -rakenteet ovat peräisin yhdeltä opiskelijaryhmältä, nimittäin tarttolaisilta suomen opiskelijoilta (edellä mainituista 63 tapauksesta vain kolme tekee tästä poikkeuksen). Rakenteen käyttöön ei kuitenkaan löydy selitystä oppikirjasta, sillä siinä rakennetta ei ole esitelty eivätkä samaa oppikirjaa käyttävät tallinnalaiset opiskelijatkaan ole tuottaneet näitä rakenteita. On myös hyvä huomata, että kun nämä erityiset rakenteet poistetaan aineistosta, PTV.sG on edelleen tilastollisin perustein ylikäytetty. Tiivistäen voi esittää, että muoto PTV.sG kolligoi eksistentiaalilauseen ja numeraalien kanssa ja sillä on ainakin osittainen semanttinen preferenssi 'perhe' (etenkin tarttolaisilla opiskelijoilla).

6 Hakulausekkeet "perheessäni on * ihmistä" / "perheessä on * ihmistä”. (Googlehakukoneella on mahdollista hakea tietoa myös korvausmerkein, tässä asteriskin avulla.) 


\subsection{Tapaus PITÄÄ}

Toisena tapauksena tutkimuksessamme on monimerkityksinen verbi рIтÄÄ. Verbin täydennykset ja eri merkitykset ovat yhteydessä toisiinsa (ISK $2004 \S 449$ ), joten kun tarkastellaan verbin kerasanojen morfologisia piirteitä, ei voida välttää tutkimasta myös verbin eri merkityksiä. "Kielitoimiston sanakirja" (KS s.v. pitää) antaa verbille 18 erilaista merkitystä, joista tärkeimmät voidaan kuitenkin niputtaa neljän erilaisen rakenteen alle. Ensimmäinen on transitiivisen PITÄ̈̈-verbin ja sen olosijaisen täydennyksen muodostama rakenne, jota "Iso suomen kielioppi" (2004 \$475) nimittää pitämismuotiksi. Rakenteen adverbiaalitäydennys voi olla lokatiivinen, habitiivinen tai predikoiva. (Pitää jotakin kädessä $\sim$ pystyssä käymässä.) Tämän rakenteen alle niputtuvat verbin jonkinlaiseen säilyttämiseen, pitämiseen ja pysyttämiseen (otteessa, asemassa, tilassa) liittyvät merkitykset (10).

Toinen selvästi erottuva merkitysrypäs liittyy kannanoton ja mielipiteen ilmaisemiseen. Siihen liittyvät merkitykset jakaantuvat rakenteellisesti kahteen ryhmään: Jonkin arvioimista jonkinlaiseksi ('pitää jotakin jonakin’) “Iso suomen kielioppi” (2004\$485) nimittää arviointimuotiksi (11). Siinä PIтÄÄ-verbiin liittyy essiivimuotoinen predikatiiviadverbiaali ja (partitiivi)objekti, joka voi olla myös A-infinitiivi. Toinen arviointiin liittyvä rakenne ilmaisee 'tykkäämistä', ja siinä verbi saa rektiokseen elatiivimuotoisen täydennyksen (12). PITÄ̈̈-verbi esiintyy myös nesessiivirakenteessa (13), jolloin se on yksipersoonainen: sen predikaattiverbi on aina yksikön kolmannessa persoonassa. Rakenteen ilmisubjekti on genetiivimuotoinen, ja subjektittomissa tapauksissa lause tulkitaan yleensä nollapersoonaiseksi (ISK $2004 \$ 1354$ ). PITÄÄ-verbillä on runsaasti myös muita merkityksiä, joista useille on tyypillistä fraasimaisuus (esim. PITÄÄ LOMAA, PITÄ̈̈ HAUSKAA, PITÄÄ HUOLTA).

(10) Hän pitää kädessään sateenvarjoa.

(11) Hän pitää tätä hyvänä ideana.

(12) Hän pitää suklaasta.

(13) Hänen pitää lähteä. 
Kielenoppijoiden tuottamien verbinmuotojen frekvenssit ja variaatiot eroavat sekä osakorpuksittain toisiinsa että suhteessa natiivisuomeen. Muotojen kirjo on odotetusti kapeampi kuin natiivipuhujien, ja oppijansuomessa on odotuksenmukaisesti enemmän virheellisiä muotoja kuin toimitettuun aineistoon pohjautuvassa natiivikielen vertailuaineistossa, jossa ainoat norminvastaiset muodot ovat murteellisia pittää-muotoja. Mielenkiintoista on, että ICLFI-multi-aineisto eroaa sekä muotojen variaatiota että frekvenssejä tarkasteltaessa vähemmän natiivikielestä kuin ICLFI-viro, sillä sukukielisten opiskelijoiden tuotosten voisi odottaa olevan lähempänä kohdekieltä (Ks. Lähdekielen vaikutuksesta Kaivapalu 2005; Kaivapalu \& Eslon 2011). Edellä tarkastellussa IHMINEN-tapauksessahan tilanne oli juuri näin.

Erityisen kiinnostavia ovat oppijankielessä hyvin yleiset muodot pidän ja pitää, joiden esiintymien määrat eroavat sekä ICLFI-multi- että ICLFI-viro-aineistossa merkitsevästi natiiviaineistosta ${ }^{7}$. Merkitsevin ero on muodossa pidän, joka on ICLFI-viro-aineiston yleisin muoto ja kattaa 36 prosenttia kaikista PITÄ̈̈-verbin muodoista. ICLFI-multiaineistossakin se on hyvin yleinen (24\%), kun taas natiivisuomessa sitä käytetään vain hyvin vähän $(1,3 \%)^{8}$. Tämä osoittaa, että vaikka ICLFI-multi-aineiston fraseologisen yksikön ytimessä olevan РIтÄ̈̈verbin morfologinen priming on selvästi erilainen kuin natiivikielessä, eroaa virolaisten kielenoppijoiden priming sitäkin enemmän kohdekielestä.

Seuraavaksi siirrymme ytimen morfologisesta primingista sen kerasanojen morfofonologisiin muotoihin ja tarkastelemme erilaisia täydennysympäristöjä, jotka reaalistuvat verbin eri merkityksissä. Merkitysvarianttien käyttö eroaa jälleen sekä osakorpuksittain että suhteessa natiivisuomeen. Analyysin kohteeksi on valikoitunut ytimen

\footnotetext{
7 ICFLI-viro vs. natiiviaineisto $\mathrm{x}^{2}=2113,99$, ICLFI-multi vs. natiiviaineisto $\mathrm{x}^{2}=$ 2049,10; ICLFI-viro vs. ICLFI-multi $\mathrm{x}^{2}=51,16$ ( $\mathrm{df}=2, \mathrm{p}<0,0001$, kriittinen arvo 13,82).

8 Esiintymien absoluuttiset määrät ovat ICLFI-virossa 182/505, ICLFI-multissa 732/3 103 ja natiivisuomessa 135/10 439 (pidän-muoto/kokonaismäärä).
} 
morfologisessa primingissa esille nousseen, oppijankielessä yleisen pidän-muodon merkitysten jakautuma aineistoissa. Vaikka pitelymuotin kuvaama merkitys 'pitää jotakin kädessään' on sanakirjoissa (KS s.v. pitää) annettu yhdeksi perusmerkityksistä, jää se analyysin ulkopuolelle, koska se on sekä natiivisuomen että oppijankielen aineistossa hyvin harvinainen. Lisäksi nesessiivinen merkitys 'täytyä' on kieliopillisesti mahdoton ensimmäisen persoonan muodossa pidän. Näin ollen vertailu natiivikäyttöön ei ole mielekästä, vaikka suomenoppijat ovatkin tuottaneet jonkin verran nesessiivisiä merkityksiä ja rakenteita yksikön 1. persoonan muodosta. Ne näkyvät myöhemmin taulukossa 3. Muut aikaisemmin mainitut perusmerkitykset jakautuvat taulukon 2 kuvaamalla tavalla.

TAUlukкo 2. Pidän-muodon ali- ja ylikäyttö oppijankielen aineistoissa natiivisuomeen verrattuna

$\left(^{\star * \star}=\text { erittäin merkitsevä, } \mathrm{z}>3,29(=\mathrm{p}<0,001)\right)^{9}$

\begin{tabular}{|l|l|l|}
\hline Pidän-muodon merkitykset & ICLFI-viro & ICLFI-multi \\
\hline 'tykätä' & ylikäyttö $^{* * *}$ & ylikäyttö $^{* * *}$ \\
\hline 'arvioida' & alikäyttöö$^{* * *}$ & alikäyttöö$^{* * *}$ \\
\hline fraasit & alikäyttö $^{* * *}$ & alikäyttö $^{* * *}$ \\
\hline
\end{tabular}

Sekä ICLFI-viro- että ICLFI-multi-aineistoissa merkitys 'tykätä’ on selvästi yliedustunut ja essiivimuodon sisältävä arviointimuotti ('pitää jotakin jonakin') on aliedustunut. Itse asiassa virolaiset suomenoppijat käyttävät liki yksinomaan pidän-muotoa merkityksessä 'tykätä: sen osuus on 99 prosenttia kaikista muodon esiintymistä $(14,15)$. Elatii-

9 'tykätä': ICFLI-viro vs. natiiviaineisto $\mathrm{z}=11,488$ ( $\mathrm{p}<0,001)$, ICLFI-multi vs. natiiviaineisto $\mathrm{z}=13,606(\mathrm{p}<0,001)$

'arvioida': ICFLI-viro vs. natiiviaineisto $\mathrm{z}=6,560$ ( $\mathrm{p}<0,001$ ), ICLFI-multi vs. natiiviaineisto $\mathrm{z}=6,130(\mathrm{p}<0,001)$

Fraasit: ICFLI-viro vs. natiiviaineisto $\mathrm{z}=8,840$ ( $\mathrm{p}<0,001$ ), ICLFI-multi vs. natiiviaineisto $\mathrm{z}=13,677(\mathrm{p}<0,001)$. 
vitäydennyksisen 'tykätä-merkityksen prosenttiosuus on suuri myös ICLFI-multi-oppijoilla (90\%), mutta tässä aineistossa esiintyy jonkin verran (6 \%) myös essiivirakenteita (16), vaikkakin ero kohdekieleen on selvä: natiivisuomessa 'tykätä'-merkityksiä on 42 prosenttia ja essiivirakenteellisia arviointeja 22 prosenttia kaikista käyttötavoista. Myös fraasimaisia ilmauksia oppijansuomessa käytetään selvästi vähemmän kuin natiivisuomessa. Virolaiset eivät tuota niitä lainkaan, ja ICLFImulti-aineiston suomenoppijoilla niitä on 2 prosenttia kaikista pidänmuodoista (17). Natiivisuomessa fraasien osuus on niinkin suuri kuin 36 prosenttia. Tämä osoittaa, että myös verbin täydennyksenä olevien kerasanojen morfologiset primingit eroavat selvästi kohdekielestä ja myös tässä tapauksessa ICLFI-viro eroaa siitä enemmän kuin moniäidinkielinen aineisto.

(14) Pidän kovin musiikista. (VI0276C)

(15) Pidän tämästä elokuvasta. (ES0007)

(16) Pidän suomea vaikeana kielenä. (SA0024)

(17) Pidän hauskaa aina. (KI0009F)

Seuraavaksi tarkastellaan tarkemmin oppijakielelle tyypillisen pidänmuodon yllättävän vahvaa semanttista primingia merkityksen 'tykätä' kanssa. Taulukko 3 esittää, miten pidän-muodot jakautuvat taitotasoittain arvioituina.

Liki kaikki viron aineiston pidän-muodot ovat alkeistasolla olevien opiskelijoiden tuottamia. Se, että merkitys 'tykätä' on korostunut (99 \%), selittynee ainakin osin sillä, että rakennetta pitää jostakin harjoitellaan kielenoppimisen alkuvaiheessa runsaasti, mutta se ei kuitenkaan selitä kyseisen fraseologisen yksikön täydellistä puuttumista muilta taitotasoilta. Toinen mahdollinen selitys on, että ICLFI-viron aineistossa yleinen tehtävätyyppi, kuvaus, ja tehtävänannot (Perheeni, Päiväni) ohjaavat käyttämään kyseistä rakennetta. Jälkimmäinen vaihtoehto indikoi sitä, että rakenteen ja sen myötä 'tykätä'-merkityksen ja tekstilajien sekä myös tehtävänantojen välillä on Hoeyn $(2005 ; 2007)$ mainitsemaa tekstuaalista primingia. 
TAuluкKо 3. Pidän-muodon jakautuminen eri merkityksiin taitotasoittain oppijankielen aineistoissa ja natiivisuomessa. (Alkeistaso: < 200 tuntia opetusta; keskitaso: 200-400 tuntia opetusta; edistyneet: $>400$ tuntia opetusta)

\begin{tabular}{|c|c|c|c|c|c|c|c|}
\hline \multirow{2}{*}{$\begin{array}{l}\text { Pidän- } \\
\text { muodon } \\
\text { merki- } \\
\text { tykset }\end{array}$} & \multicolumn{3}{|c|}{ ICLFI-viro } & \multicolumn{3}{|c|}{ ICLFI-multi } & \multirow[b]{2}{*}{$\begin{array}{c}\text { natiivi- } \\
\text { suomi }\end{array}$} \\
\hline & $\begin{array}{c}\text { alkeis- } \\
\text { taso }\end{array}$ & $\begin{array}{c}\text { keski- } \\
\text { taso }\end{array}$ & $\begin{array}{c}\text { edisty- } \\
\text { neet }\end{array}$ & $\begin{array}{c}\text { alkeis- } \\
\text { taso }\end{array}$ & $\begin{array}{c}\text { keski- } \\
\text { taso }\end{array}$ & $\begin{array}{c}\text { edisty- } \\
\text { neet }\end{array}$ & \\
\hline 'tykätä' & $\begin{array}{r}177 \\
(99 \%) \\
\end{array}$ & 2 & - & $\begin{array}{r}351 \\
(94 \%) \\
\end{array}$ & $\begin{array}{r}203 \\
(92 \%) \\
\end{array}$ & $\begin{array}{r}107 \\
(76 \%) \\
\end{array}$ & $\begin{array}{r}57 \\
(42 \%) \\
\end{array}$ \\
\hline 'arvioida' & $0 \%$ & - & 1 & $0 \%$ & $\begin{array}{r}13 \\
(6 \%) \\
\end{array}$ & $\begin{array}{r}29 \\
(21 \%) \\
\end{array}$ & $\begin{array}{r}29 \\
(22 \%) \\
\end{array}$ \\
\hline fraasit & $0 \%$ & - & - & $9(2 \%)$ & $4(2 \%)$ & $4(3 \%)$ & $49(36 \%)$ \\
\hline 'täytyä' & $2(1 \%)$ & - & - & $6(2 \%)$ & $0 \%$ & $0 \%$ & $0 \%$ \\
\hline muut & $0 \%$ & - & - & $6(2 \%)$ & $0 \%$ & $0 \%$ & $0 \%$ \\
\hline yhteensä & $\begin{array}{r}179 \\
(100 \%)\end{array}$ & 2 & 1 & $\begin{array}{r}372 \\
(100 \%)\end{array}$ & $\begin{array}{r}220 \\
(100 \%)\end{array}$ & $\begin{array}{r}140 \\
(100 \%)\end{array}$ & $\begin{array}{r}135 \\
(100 \%)\end{array}$ \\
\hline
\end{tabular}

Analyysi ei paljasta, onko rakenne yhtä dominoiva ICLFI-viro-aineistossa muidenkin PITÄ̈̈-verbin muotojen kohdalla, eikä sitä, onko muiden muotojen merkitysjakauma ehkä toisenlainen. Kovin merkittäviä eroja ei kuitenkaan löytyne, koska aiemminhan kävi jo ilmi, että nimenomaan muoto pidän on viron aineistossa selvästi yleisin ja muiden muotojen käyttö on hyvin vähäistä. ICLFI-multi-korpuksen analyysi kertoo, että myös tässä aineistossa alkeis- ja keskitasolla merkitys 'tykätä' on selvästi yleisin, molemmissa yli 90 prosenttia. Edistyneillä prosenttiosuus (76\%) on kuitenkin jo selvästi pienempi, joten tämän aineiston perusteella voimme sanoa, että verbimuodon käyttö lähestyy vähitellen natiivikäyttöä (42\%) taitotason parantuessa. Selvimmin tendenssi näkyy kuitenkin tarkasteltaessa essiivilaajennuksen sisältävää merkitystä 'arvioida'. Näitä rakenteita edistyneet ICLFI-multi-oppijat käyttävät liki yhtä usein kuin natiivipuhujat. Prosenttiosuuksissa on vain yhden prosenttiyksikön ero (21\% ja $22 \%)$. Rakenteet löytyvät usein esseistä ja mielipidekirjoi- 
tuksista, joiden kanssa muodolla ja siihen liittyvällä arviointimerkityksellä tuntuisi olevan tekstuaalista primingia.

On kuitenkin pantava merkille, että verbin fraasimainen käyttö ei lisäänny liki lainkaan taitotason kasvaessa. Edistyneilläkin kielenoppijoilla pidän-muodon sisältäviä fraaseja on vain 3 prosenttia, kun vastaava luku natiivisuomessa on peräti 36 prosenttia. Mielenkiintoisella tavalla - tämän analyysin perusteella - ilmiö tiivistyy kuitenkin juuri pidän-muotoon, sillä analysoitaessa pitää-muotoa (joka voi olla paitsi 1INF myös 3SG) nähdään, että prosenttiosuudet ovat liki samat: ICLFImulti-aineistossa edistyneiden kielenoppijoiden tuottamista pitäämuodoista on fraasimaisia ilmauksia 19 prosenttia ja natiivisuomessa 20 prosenttia. Voimmekin sanoa, että fraaseilla (PITÄÄ LOMAA, PITÄ̈̈ HAUSKAA, PITÄÄ HUOLTA) on oppijankielessä positiivinen morfologinen priming muotoon pitää, mutta negatiivinen priming muotoon pidän. Lisäksi ICLFI-multi-aineiston pitää-muodon fraasien frekventuaalinen osuus on hyvin samanlaista kuin natiivisuomessa; siltä osin morfologinen priming on hyvin kohdekielimäistä, päinvastoin kuin pidän-muodossa. Mahdollinen selitys ilmiölle on, että fraasit opitaan usein juuri perusmuodoissaan. Vaikka oppijakielen fraasit ovatkin usein yksinkertaisia fraseologisia yksiköitä kuten pitää huolta, pitää hauskaa (18), ei fraasien käyttö rajoitu vain niihin vaan fraasien joukossa on mukana myös muita, esimerkiksi esittämiseen ja järjestämiseen liittyviä fraaseja $(19,20)$.

(18) Ei ole paljon aikaa pitää hauskaa. (KI0014D)

(19) --- psykologi pitää esitelmän itsemurhista ---. (PU0005O)

(20) Faarao pitää suuret juhlat maansa kunniaksi. (VE00100)

\section{Morfofonologiset virheet sanan taivutuksessa}

Yksi hypoteeseistamme oli, että äidinkielenään sukukieltä puhuvat kielenoppijat (tässä tutkimuksessa virolaiset) tuottavat morfofonologisesti epätyypillisiä ja virheellisiä taivutusmuotoja vähemmän kuin muut, kielitaustaltaan esimerkiksi indoeurooppalaiset opiskelijat. Hypoteesin 
testaamiseksi laskimme kaikki IHMINEN-nominin tuotoksissa esiintyvät epätyypillisyydet. Taivutusmuodoissa esiintyi virheitä, jotka on tulkittavissa kirjoitusvirheiksi ja ehkä myös vartalon hahmottamisen virheiksi (21) ja sekä vokaaliharmoniaongelmiksi (22); jälkimmäinen ongelma on tavallinen vironkielisilläkin oppijoilla. PIтÄ̈̈-verbin osalta keskityimme konsonanttivaihtelussa ja sitä läheisesti muistuttavassa passiiviin tunnuksen konsonanttien vaihtelussa esiintyviin virheisiin, koska ne aiheuttavat runsaasti ongelmia indoeurooppalaisille kielenoppijoille ja käänteinen astevaihtelu myös sukulaiskielen oppijoille (ks. Kaivapalu 2005: 51). Astevaihteluvirheitä voi esiintyä sekä verbin vartalossa että passiivimuodon tunnuksessa, mutta koska passiivimuodot olivat molemmissa aineistoissa hyvin harvinaisia, löytyi pääosa virheistä vartalosta $(23,24) .^{10}$

(21) Joka osastossa on kaksi huonettä kahden ihemesen varten, keittiö ja kylpy. (VE0175a)

(22) Minun perhessa on kolme ihmista- minä, minun äiti ja minun veli. (VI0277)

(23) Hän pidää musiikista, mutta hän ei laula. (VI0116A)

(24) Minä pitän opiskelemisesta Potznanissa. (PU0036)

Toisin kuin useissa aikaisemmissa tutkimuksissa (esim. Kaivapalu 2005; Kaivapalu \& Eslon 2011) ei meidän analyysimme mukaan sukulaiskielellä ole positiivista vaikutusta tuotoksen laatuun. Tapauksessa IHMINEN ICLFI-multi-aineistossa virheellisiä muotoja on 6,1, prosenttia, kun taas ICLFI-virossa niitä on 5,9 prosenttia. Myös tapauksessa PITÄÄ prosenttiosuudet ovat liki samat: ICLFI-multi-aineistossa 6,6 \% ja ICLFI-virossa 6,4 \%. Käyttämiemme aineistojen ja tutkimamme kahden tapauksen perusteella emme siis voi väittää, että äidinkielenään sukukieltä puhuvat kielenoppijat hallitsevat taivutusmuodot muita kielen-

10 Oletuksemme on, että vaikka virolaisilla kielenoppijoilla on oman vastaavan järjestelmänsä johdosta jonkinlainen käsitys suomen konsonanttivaihtelusta, voivat vaihtelun eroavaisuudet aiheuttaa heille ongelmia. On myös muistettava, että aina ei voi tehdä eroa taivutusvirheiden ja pelkkien kirjoitusvirheiden välille. 
oppijoita paremmin. On toki otettava huomioon, että aineistot eivät ole täysin vertailukelpoisia taitotasoiltaan: ICLFI-viro-aineistossa on erittäin paljon tasoilla B1-olevia, meidän luokituksessamme alkeistasolle sijoittuvia kielenoppijoita, mikä näkyy erityisesti PITÄÄ-verbin tuotoksissa.

\section{Tuloksia ja pohdintaa}

Tutkimustulostemme perusteella voimme väittää, että fraseologia ja morfologinen priming ovat yhteydessä toisiinsa. Koska kielenoppijat tuottavat epätyypillisiä fraseologisia yksiköitä, myös heidän paradigmaattinen morfologinen priminginsa eroaa natiivipuhujien primingista.

Tutkimuksemme osoittavat, että suomea vieraana kielenä opiskelevat kielenoppijat eivät hallitse fraseologisen yksikön ytimen paradigmaattista morfologista primingia samalla tavalla kuin natiivipuhujat. Tämä näkyy erityisesti siinä, että kielenoppijoiden tuottamien erilaisten taivutusmuotojen frekvenssit eroavat selvästi natiivipuhujien tuottamista muodoista. Sekä tapauksessa IHMINEN että PITÄÄ löytyy tilastollisesti merkitseviä yli- ja aliedustumisia. Oppijankielen fraseologisen yksikön ytimen paradigmaattinen valinta siis eroaa kohdekielestä.

Myös ytimen ja sen kerasanojen muodostaman kokonaisuuden eli fraseologisen yksikön - morfologinen priming on erilaista oppijankielessä kuin kohdekielessä.

Yhtenä mahdollisena syynä epätyypilliseen morfologiseen primingiin on kielenoppijoiden pyrkimys välttää tiettyjä muotoja. Tämä näkyy esimerkiksi nominin ihminen suosimisessa morfofonologisesti monimutkaisen passiivimuodon sijasta. Kohdekielestä poikkeavat epätyypilliset primingit voivat olla myös rakenteellisesti hyvänmuotoisia ilmauksia kuten perheessäni on \# ihmistä, jotka natiivikielessä kuitenkin ovat hyvin harvinaisia. Kielenoppijoiden käyttämien PIтÄ̈̈-verbin eri merkitysten variaatio on selvästi kapeampi kuin natiivipuhujien ja tietyt, usein konkreettiset ja opetuksessa painotetut rakenteet ja sitä myötä merkitykset korostuvat muiden kustannuksella: tutkimuksemme kielenoppijoiden 
tuottamat pidän-muodot liittyvät selvästi yleisimmin elatiivitäydennyksiseen merkitykseen 'tykätä. Mielenkiintoista kuitenkin on, että verbin muoto vaikuttaa merkitysvariaatioiden käyttöön: muodolla pitää on positiivinen priming verbin fraasikäyttöön kun taas muodolla pidän priming on negatiivinen. Näin pilottitutkimuksemme vahvistaa Sinclairin (1991: 8) ja Stubbsin (2001: 17) käsitystä, että leksikaalisia (fraseologisia) yksiköitä ei pitäisi tarkastella yksinomaan lemmatasolla, elleivät lemman eri taivutusmuotojen syntagmaattiset valinnat ole yhteneviä. Erityisen tärkeää tämä on silloin, kun tutkimuskohteena on kieli, jolla on rikas morfosyntaktinen taivutusjärjestelmä.

Aikaisemmista tutkimuksista poiketen analyysimme osoittaa, että kielenoppijan äidinkielellä ei näytä olevan suoranaista vaikutusta käytettyjen muotojen virheettömyyteen - tosin tutkimamme kahden tapauksen tulokset ovat kiinnostavalla tavalla vastakkaisia: tapauksessa IHMINEN sukukielen puhujien priming on lähempänä natiivipuhujien kielenkäyttöä kuin äidinkielenään ei-sukukieltä puhuvien kielenoppijoiden, mutta tapauksessa PITÄ̈̈ tulos on päinvastainen. On kuitenkin otettava huomioon, että tulosten taustalla voi olla monia muitakin muuttujia. Käytetyt oppikirjat, opetusmetodit, opettajan äidinkieli sekä tietysti tehtävänannot ja niiden ohjeistus voivat vaikuttaa sekä fraseologisten yksiköiden muodostumiseen että tuotettuihin morfologisiin muotoihin ja sitä myötä kielenoppijoiden tuottamaan morfologiseen primingiin. Yhtä kaikki tämä pilottiluonteinen kahden tapauksen tarkastelu paljastaa fraseologisuuden ja morfologisen primingin keskinäisen vaikutuksen olomassaolon ja osoittaa, että morfologinen priming vaatii runsaasti lisätutkimusta siinä missä ylipäätään fraseologinen osaaminen ja siinä kehittyminenkin.

\section{Kiitokset}

Tutkimusta ovat tukeneet Riksbankens Jubileumsfond (F10-0421:1) ja Oulun yliopisto. Kiitämme myös nimettömiä arvioijia hyödyllisistä kommenteista. 


\section{Lyhenteet}

$\begin{array}{ll}1 & \text { ensimmäinen persoona } \\ 3 & \text { kolmas persoona } \\ \text { GEN } & \text { genetiivi } \\ \text { INF } & \text { infinitiivi } \\ \text { NOM } & \text { nominatiivi } \\ \text { NP } & \text { nominilauseke } \\ \text { PL } & \text { monikko } \\ \text { PTV } & \text { partitiivi } \\ \text { SG } & \text { yksikkö }\end{array}$

\section{Lähteet}

Aston, Guy, Lou Burnard 1998. The BNC Handbook. Exploring the British National Corpus with SARA. Edinburgh: Edinburgh University Press.

Dose, Stephanie 2010. Patterns of growing standardisation and interference in interpreted German discourse. MA Dissertation. University of South Africa. http://uir.unisa.ac.za/xmlui/handle/10500/4710?show=full (17.3.2012).

Ellis, Nick C. 2008. Phraseology: The periphery and the heart of language. - Fanny Meunier, Sylviane Granger (Eds.). Phraseology in Foreign Language Learning and Teaching. Amsterdam: John Benjamins, 1-13.

Granger, Sylviane 1996. From CA to CIA and back: An integrated approach to computerized bilingual and learner corpora. - Karin Aijmer, Bengt Altenberg, Mats Johansson (Eds.). Languages in Contrast. Text-based Crosslinguistic Studies. Lund: Lund University Press, 37-51.

Granger, Sylviane 1998. Prefabricated patterns in advanced EFL writing: Collocations and formulae. - Anthony Paul Cowie (Ed.). Phraseology: Theory, Analysis and Applications. Oxford: Oxford University Press, 145-160.

Hasselgren, Angela 1994. Lexical teddy bears and advanced learners: a study into the ways Norwegian students cope with English vocabulary. - International Journal of Applied Linguistics 4 (2), 237-260. http://dx.doi. org/10.1111/j.1473-4192.1994.tb00065.x

Hoey, Michael 2005. Lexical Priming. A New Theory of Words and Language. London: Routledge.

Hoey, Michael 2007. Lexical priming and literary creativity. - Michael Hoey, Michaela Mahlberg, Michael Stubbs, Wolfgang Teubert (Eds.). Text, Discourse and Corpora. Theory and Analysis. London: Continuum, 7-29. 
ISK = Hakulinen, Auli, Maria Vilkuna, Riitta Korhonen, Vesa Koivisto, Tarja-Riitta Heinonen, Irja Alho 2004. Iso suomen kielioppi. Suomalaisen Kirjallisuuden Seuran toimituksia 950. Helsinki: Suomalaisen Kirjallisuuden Seura.

Jantunen, Jarmo H. 2001. Tärkeä seikka ja keskeinen kysymys: Mitä korpuslingvistinen analyysi paljastaa lähisynonyymeista? - Virittäjä 105 (2), 170-192.

Jantunen, Jarmo H. 2004a. Synonymia ja käännössuomi. Korpusnäkökulma samamerkityksisyyden kontekstuaalisuuteen ja käännöskielen leksikaalisiin erityispiirteisiin. Joensuun yliopiston humanistisia julkaisuja 35. Joensuu: Joensuun yliopisto.

Jantunen, Jarmo H. 2004b. Untypical patterns in translations. Issues on corpus methodology and synonymity. - Anna Mauranen, Pekka Kujamäki (Eds.). Translation Universals. Do they Exist? Amsterdam: John Benjamins, 101126.

Jantunen, Jarmo H. 2007. Oppijansuomen piirteitä korpusvetoisesti. - Pirkko Muikku-Werner, Ossi Kokko, Hannu Remes (Toim.). Virsu 3. Suomalaisugrilaisia kohdekieliä ja kontakteja. Studies in Languages 42. Joensuu: Joensuun yliopisto, 69-83.

Jantunen, Jarmo H. 2009a. Ei pelkästään mielikuvituksen puutteen vuoksi. Kieliaineistojen systemaattinen käyttö kielentutkimuksessa. - Virittäjä 113 (1), 101-113.

Jantunen, Jarmo H. 2009b. Minulla on aivan paljon rahaa. Fraseologiset yksiköt suomen kielen opetuksessa. - Virittäjä 113 (3), 356-381.

Jantunen, Jarmo H. 2011a. Avainsana-analyysi annotoiduin oppijankieliaineiston tutkimisessa: alustavia havaintoja. - Esa Lehtinen, Sirkku Aaltonen, Merja Koskela, Elina Nevasaari, Mariann Skog-Södersved (Toim.). AFinLA-e: Soveltavan kielitieteen tutkimuksia 3, 48-61. http://ojs.tsv.fi/index.php/ afinla (16.3.2012).

Jantunen, Jarmo H. 2011b. Kansainvälinen oppijansuomen korpus (ICLFI): typologia, taustamuuttujat ja annotointi. - Lähivõrdlusi. Lähivertailuja 21, 86-105. http://dx.doi.org/10.5128/LV21.04

Jantunen, Jarmo H. 2012. Korpusvetoinen tekstilajianalyysi: sanalistat ja genreavainsanat. - Vesa Heikkinen, Eero Voutilainen, Petri Lauerma, Ulla Tiililä, Mikko Lounela (Toim.). Genreanalyysi - tekstilajitutkimuksen käsikirja. Helsinki: Gaudeamus.

Kaivapalu, Annekatrin 2005. Lähdekieli kielenoppimisen apuna. Jyväskylä Studies in Humanities 44. Jyväskylä: Jyväskylän yliopisto.

Kaivapalu, Annekatrin, Pille Eslon 2011. Onko lähisukukielen vaikutus suomen ja viron omaksumiseen symmetristä. Korpuspohjaisen tutkimuksen tuloksia 
ja haasteita. - Lähivertailuja. Lähivõrdlusi 21, 132-151. http://dx.doi. org/10.5128/LV21.06

Kallioranta, Otto 2009. Paljon-adverbin kollokointi oppijansuomessa: Korpusvetoinen tutkimus. Pro gradu -tutkielma. Oulun yliopisto, suomen kieli.

Kaszubski, Przemek 2000. Selected Aspects of Lexicon, Phraseology and Style in the Writing of Polish Advanced Learners of English: A Contrastive, Corpus-Based Approach. Poznań: Adam Mickiewicz University.

$\mathrm{KS}=$ Kielitoimiston sanakirja 2008. Kotimaisten kielten tutkimuskeskuksen julkaisuja 149. Helsinki: Kotimaisten kielten tutkimuskeskus ja Kielikone.

Kubáčková, Jana 2009. Keeping Czech in check: A corpus-based study of generalization in translation. - SKASE Journal of Translation and Interpretation 4 (1), 33-51. http://www.skase.sk/Volumes/JTI04/pdf doc/03.pdf (17.3.2012).

Martin, Maisa, Sanna Mustonen, Nina Reiman, Marja Seilonen 2010. On becoming an independent user. - Inge Bartning, Maisa Martin, Ineke Vedder (Eds.). Communicative Proficiency and Linguistic Development: Intersections Between SLA and Language Testing Research. Eurosla Monographs Series 1. Eurosla, 57-79.

Mauranen, Anna 2000. Strange strings in translated language. A study on corpora. - Maeve Olohan (Ed.). Intercultural Faultlines. Research Models in Translation Studies I. Textual and Cognitive Aspects. Manchester: St. Jerome, 119-141.

McNamara, Timothy P. 2005. Semantic Priming. Perspectives from Memory and Word Recognition. New York: Psychology Press. http://dx.doi. org/10.4324/9780203338001

Meunier, Fanny, Sylviane Granger 2008. Phraseology in Foreign Language Learning and Teaching. Amsterdam: John Benjamins.

Neely, James H. 1991. Semantic priming effects in visual word recognition. A selective review of current findings and theories. - Derek Besner, Glyn W. Humphreys (Eds.). Basic Processes in Reading: Visual Word Recognition. Hillsdale, NJ: Erlbaum, 264-336.

Nesselhauf, Nadja 2003. The use of collocations by advanced learners of English and some implications for teaching. - Applied Linguistics 24 (2), 223-242. http://dx.doi.org/10.1093/applin/24.2.223

Nesselhauf, Nadja 2005. Collocations in a Learner Corpus. Amsterdam: John Benjamins.

Nesselhauf, Nadja 2009. Co-selection phenomena across New Englishes. Parallels (and differences) to foreign learner varieties. - English World-Wide 30 (1), 1-25. http://dx.doi.org/10.1075/eww.30.1.02nes 
Scott, Mike 2004. WordSmith Tools version 4. Oxford: Oxford University Press.

Scott, Mike, Christopher Tribble 2006. Textual Patterns. Key Words and Corpus Analysis in Language Education. Studies in Corpus Linguistics 22. Amsterdam: John Benjamins.

Seilonen, Marja 2011. Olemattoman ilmaiseminen. - Esitelmä Suomen kielen ja kulttuurin opettajien opinto- ja neuvottelupäivillä Kuopiossa 4.8.2011.

Sinclair, John 1991. Corpus, Concordance, Collocation. Oxford: Oxford University Press.

Sinclair, John 1996. The Search for Units of Meaning. - Textus IX, 75-106.

Stubbs, Michael 2001. Words and Phrases. Corpus Studies of Lexical Semantics. Oxford: Blackwell.

Tognini-Bonelli, Elena 1996. Corpus Theory and Practice. Birmingham: TWC.

Tsui, Amy B. M. 2004. What teachers have always wanted to know - and how corpora can help. - John Sinclair (Ed.). How to Use Corpora in Language Teaching. Studies in Corpus Linguistics 12. Amsterdam: John Benjamins, 39-61.

Tsui, Amy B. M. 2005. ESL teachers' questions and corpus evidence. - International Journal of Corpus Linguistics 10 (3), 335-356. http://dx.doi.org/10.1075/ ijcl.10.3.03tsu

Wray, Alison 1999. Formulaic language in learners and native speakers. - Language Teaching 32 (4), 213-231. http://dx.doi.org/10.1017/S0261444800014154

Wray, Alison 2000. Formulaic sequences in second language teaching. Principle and practice. - Applied Linguistics 21 (4), 463-489. http://dx.doi. org/10.1093/applin/21.4.463

\author{
Jarmo Harri Jantunen \\ Oulun yliopisto, suomi toisena ja vieraana kielenä \\ PL 1000 \\ 90014 Oulun yliopisto, Finland \\ jarmo.jantunen@oulu.fi
}

\title{
Sisko Brunni
}

Oulun yliopisto, suomen kieli

PL 1000

90014 Oulun yliopisto, Finland

sisko.brunni@oulu.fi 


\title{
Morphological priming and phraseology in second language acquisition: A corpus-study on learner Finnish
}

\author{
JARMO HARRI JANTUNEN \\ SISKO BRUNNI \\ University of Oulu \\ University of Oulu
}

This article discusses morphological priming in the second language acquisition. Morphological priming is a characteristic of both the core and cotextual items in a phraseological unit. It occurs when a word is frequently encountered in certain morphophonological forms. Similarly to lexical priming on the whole (e.g. collocations and other cotextual qualities), it poses challenges for language learners. The paper focuses on atypicalities in morphophonological forms and, in addition, describes errors in inflection. It is hypothesized that learners of Finnish have problems in morphological priming, and that learners, whose mother tongue is closely related to the target language, in which there exists inflection, produce more target like phraseological units.

Keywords: morphological priming; lexical priming; phraseology; learner Finnish; crosslinguistic transfer; corpus analysis 